„Nic nie jest tak trudne do rozpoczęcia, niebezpieczne do przeprowadzenia i nie gwarantuje powodzenia, jak

wprowadzenie nowego porządku rzeczy".

Machiavelli

\title{
WYZWANIA WSPÓLCZESNEGO ZARZĄDZANIA W JEDNOSTKACH SAMORZĄDU TERYTORIALNEGO W OBLICZU ZMIAN - ANALIZA PRZYPADKU
}

Funkcjonowanie administracji samorządowej może wywierać istotny wpływ na rozwój wspólnoty lokalnej. Niestety dotychczasowa praktyka dowodzi jednak, że w wypadku procesów związanych z zarządzaniem w samorządach terytorialnych częściej mamy do czynienia jedynie $\mathrm{z}$ administrowaniem niż z systemem zarządzania. Zarządzanie bowiem, w przeciwieństwie do administrowania, powinno być procesem, który zawiera w sobie aktywność i kreatywność ${ }^{2}$.

Artykuł jest poświęcony metodom reorganizacji, służącym usprawnieniu pracy jednostki samorządu terytorialnego. Skupiono się na jednej z wybranych metod - metodzie rozwoju instytucjonalnego. Metoda rozwoju instytucjonalnego urzędów obejmuje: analizę poziomu rozwoju instytucjonalnego, projektowanie zmian (usprawnień) instytucjonalnych, ich wdrażanie oraz monitorowanie i ocenę efektów. Dzięki obserwacji wskazanych obszarów zarządzania według określonych kryteriów można dokonać identyfikacji słabych i mocnych stron w nich występujących, a na tej podstawie badacz ma możliwość wskazania luk oraz sposobów dokonania usprawnień.

Analiza instytucjonalna dotyczy dziewięciu obszarów funkcjonowania urzędu. W artykule opisano analizę jednego z obszarów - mianowicie organizacji i funkcjonowania urzędu. Analizy dokonano na podstawie jednego z małopolskich urzędów gminy w roku 2015. Analizę organizacji i funkcjonowania urzędu oparto na modelu analizy instytucjonalnej. $\mathrm{W}$ artykule przedstawiono efekty analizy wybranego obszaru i kryteriów zarządzania urzędem.

Słowa kluczowe: zarządzanie, zarządzanie w jednostkach samorządu terytorialnego, nowe zarządzanie publiczne, organizacja i zarządzanie w urzędzie

\section{WSTĘP}

Praktyczne znaczenie zarządzania w jednostkach samorządu terytorialnego wiąże się z koniecznością ciągłego rozwiązywania problemów w realizacji zadań publicznych,

\footnotetext{
1 Joanna Stuglik, ul. Makowa 4, 32-600 Zaborze, tel.: 507034 410, e-mail: joanna.stuglik@pwszoswiecim.edu.pl

${ }^{2}$ E. Wojciechowski, Zarządzanie w samorządzie terytorialnym, Difin, Warszawa 2003, s. 13
} 
przez które zaspokajane są potrzeby mieszkańców wspólnoty lokalnej. Stąd też rosnący popyt na wiedzę, rozwiązania, metody i techniki, czyli wszystko to, co może być użyteczne w przypadku zarządzania w jednostce samorządu terytorialnego. Dlatego jednym z kluczowych czynników, służących rozwojowi wspólnot lokalnych, staje się sprawna i efektywna administracja samorządowa, inicjująca i wspierająca działania na rzecz poprawy jakości życia mieszkańców oraz rozwoju lokalnego.

Pojęcia „rozwój instytucjonalny” i „instytucjonalizm” od wielu lat cieszą się rosnącą popularnością. Terminy te występują $\mathrm{w}$ nowej ekonomii instytucjonalnej, wyrastającej z nurtu ekonomii politycznej określanej mianem instytucjonalizmu. Zwolennicy tego podejścia, tzw. instytucjonaliści, akcentują rolę społeczno-kulturowych uwarunkowań (norm, wzorców, reguł) w działaniach ekonomicznych człowieka. Pojęcia te są również obecne w socjologii. Na gruncie tej nauki podkreśla się wpływ wzorców, norm i wartości (formalnych i nieformalnych) na sposób działania organizacji (instytucji). Pojęcie „rozwój instytucjonalny" stosowane w przypadku tego artykułu rozumiane jest jako tworzenie zasad i mechanizmów oraz ich stosowanie w celu podniesienia sprawności działania urzędów administracji samorządowej w podstawowych obszarach ich aktywności ${ }^{3}$ :

- zarządzania strategicznego;

- zarządzania finansowego;

- zarządzania zasobami ludzkimi;

- $\quad$ świadczenia usług publicznych;

- $\quad$ komunikacji społecznej;

- $\quad$ tworzenia ram i warunków wspierania przedsiębiorczości.

Analiza instytucjonalna to metoda planowania rozwoju danej jednostki, która umożliwia ocenę poziomu jej rozwoju, w tym wypadku stan rozwoju urzędu gminy. Uzyskanie wysokiej efektywności funkcjonowania danej jednostki samorządu terytorialnego wymaga rzetelnego określenia zasobów, potencjału oraz dogłębnej samooceny.

Istnieje potrzeba stałego doskonalenia funkcjonowania urzędu administracji samorządowej w celu zapewnienia odpowiedniego poziomu świadczenia usług publicznych. Działania modernizacyjne powinny się odnosić do uznanego wzorca dobrego urzędu ${ }^{4}$. W artykule przedstawiono starania podejmowane w Urzędzie Gminy w jednej z małopolskich gmin miejsko-wiejskich o profesjonalizację zarządzania przez wykorzystanie metody analizy instytucjonalnej. Podstawowym celem artykułu jest zaprezentowanie zastosowania metody przygotowania urzędu do sprostania wymogom zmieniającego się otoczenia, w tym także do zmian wynikających z oczekiwań mieszkańców. Dokonano tego za pomocą podniesienia jakości funkcjonowania urzędu (w tym obsługi klientów) oraz wykorzystania innowacyjnych narzędzi zarządzania. Celami szczegółowymi są: analiza przypadku, prezentacja wyników przeprowadzonych badań oraz zaleceń, jakie zostały sformułowane na ich podstawie.

\footnotetext{
${ }^{3}$ Rozwój instytucjonalny. Poradnik dla samorzadów terytorialnych, red. S. Mazur, Małopolska Szkoła Administracji Publicznej Akademii Ekonomicznej w Krakowie, Kraków 2004, s. 13.

${ }^{4}$ A. Pawłowska, Ocena poziomu rozwoju instytucjonalnego urzędu - doświadczenia urzędu miasta Częstocho$w y$, ,Zarządzanie publiczne” 14/2 (2011), s. 55.
} 


\section{ANALIZA INSTYTUCJONALNA - CELE I OCZEKIWANIA}

Metoda rozwoju instytucjonalnego urzędów obejmuje analizę poziomu rozwoju instytucjonalnego, projektowanie zmian (usprawnień) instytucjonalnych, ich wdrażanie oraz monitorowanie i ocenę efektów. Elementami metody rozwoju instytucjonalnego są:

a) na poziomie analizy poziomu rozwoju instytucjonalnego:

- pięciostopniowe opisy stadiów rozwoju instytucjonalnego dla kryteriów zarządzania w ramach dziewięciu obszarów zarządzania;

- opisy stanów modelowych poziomu rozwoju instytucjonalnego dla każdego kryterium zarządzania;

- kwestionariusze diagnostyczne, korespondujące z opisami stadiów rozwoju instytucjonalnego, służące określeniu poziomu rozwoju instytucjonalnego jednostki;

- aplikacja komputerowa (dla samorządów gminnych) do samooceny poziomu rozwoju instytucjonalnego;

b) na poziomie projektowania usprawnień oraz wdrażania planów:

- plany rozwoju instytucjonalnego, zawierające zestawy projektów, których realizacja umożliwi podniesienie potencjału instytucjonalnego urzędu;

- Katalog narzędzi rozwoju instytucjonalnego - zawierający przykłady rozwiązań do zastosowania w jednostkach samorządu terytorialnego;

- Zarzadzanie w samorzadzie terytorialnym. Najlepsze praktyki, gdzie zamieszczono opisy projektów usprawnień pomyślnie zakończonych w jednostkach samorządu terytorialnego 5 .

Analiza instytucjonalna dotyczy dziewięciu obszarów funkcjonowania urzędu, które przedstawiono wna rysunku 1 .

\footnotetext{
${ }^{5}$ Ibidem, s. 7-8.
} 
Rys. 1. Obszary i kryteria zarządzania określone dla urzędu gminy

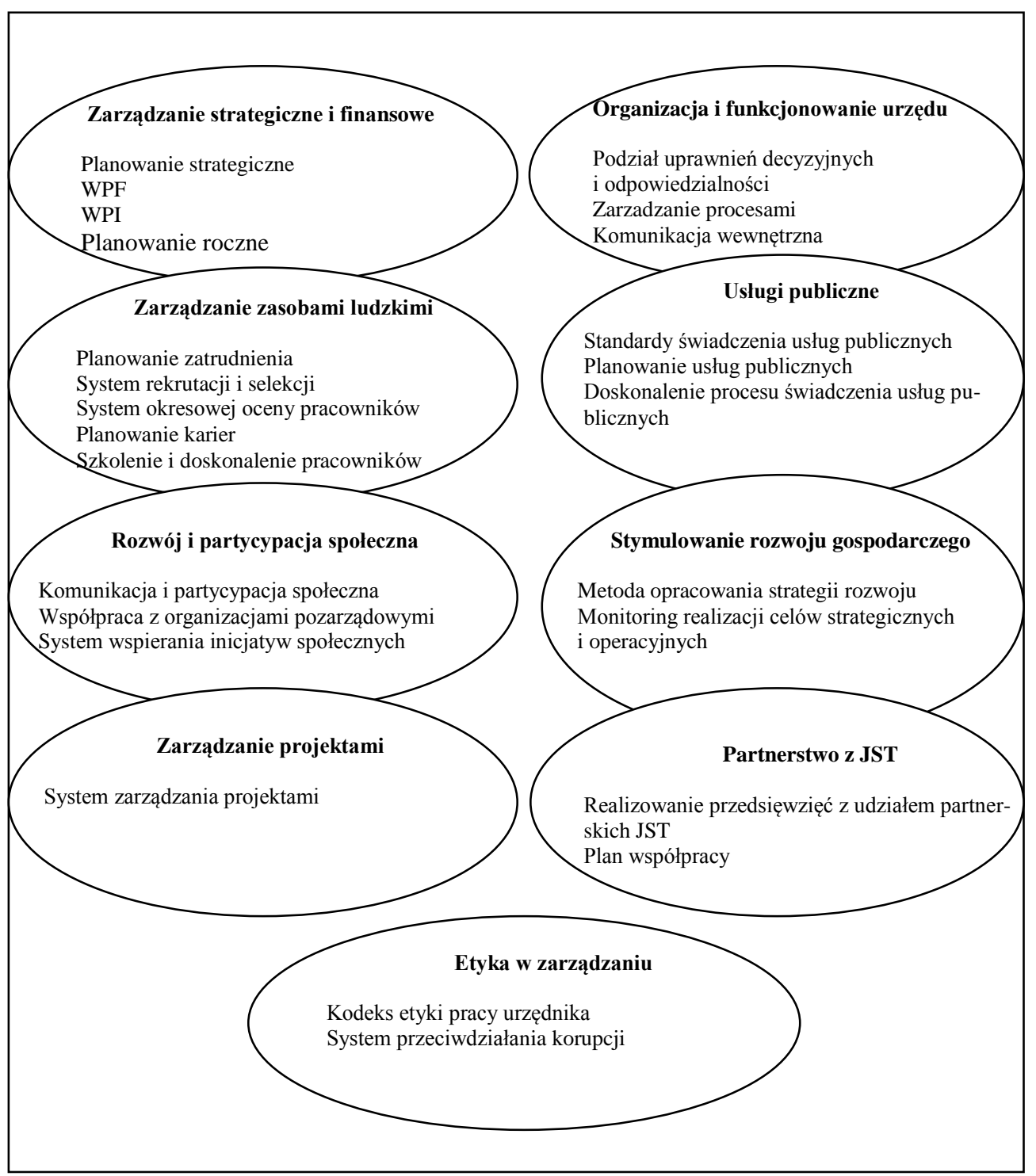

JST - jednostka samorządu terytorialnego; WPF - wieloletnie prognozowanie finansowe; WPI - wieloletnie prognozowanie inestycyjne

Źródło: opracowanie własne na podstawie: Rozwój instytucjonalny. Poradnik dla samorządów terytorialnych, red. S. Mazur, Małopolska Szkoła Administracji Publicznej Akademii Ekonomicznej w Krakowie, Kraków 2004, s. 26. 
Dzięki obserwacji wskazanych obszarów zarządzania według określonych kryteriów można dokonać identyfikacji słabych i mocnych stron w nich występujących, a na tej podstawie badacz ma możliwość wskazania luk oraz sposobów dokonania usprawnień. Taka analiza może przyczynić się w efekcie do likwidacji zbędnych elementów oraz poprawy istniejących, a także do usprawnienia procedur oraz systemu komunikacji wewnątrz urzędu. W rezultacie praca urzędu powinna przebiegać sprawniej, decyzje powinny zapadać szybciej, a beneficjent pracy urzędu - obywatel - powinien być bardziej usatysfakcjonowany.

\section{PRZEBIEG BADAŃ}

Badanie zostało zrealizowane w 2015 r. na przykładzie jednej wybranej gminy miejsko-wiejskiej w województwie małopolskim. Przeprowadzone badania dotyczyły jednego wskazanego obszaru zarządzania, mianowicie punktu Organizacja i funkcjonowanie urzędu, w zakresie trzech kryteriów: podział uprawnień decyzyjnych, zarządzanie procesami i efektywność komunikacji wewnętrznej. W ramach wskazanych kryteriów zbadano: strukturę organizacyjną (jej kształt, zależności pomiędzy poszczególnymi komórkami organizacyjnymi, działami oraz pionami), procedury organizacyjne (metodologię ich opracowania, sposób ich realizacji) i komunikację wewnętrzną (jej zasady, procedury, skuteczność, niezbędne przepływy informacyjno-decyzyjne, umożliwiające realizację procedur i sprawną koordynację). W obrębie przyjętych kryteriów została dokonana ocena poziomu rozwoju instytucjonalnego urzędu gminy.

W ramach kryterium podzial uprawnień decyzyjnych i odpowiedzialności ocenie poddano:

- przejrzystość podziału kompetencji pomiędzy radą a burmistrzem;

- przejrzystość podziału kompetencji pomiędzy burmistrzem i kierownikami;

- określenie stanowisk rozliczanych za rezultaty zrealizowanych zadań;

- określenie stanowisk odpowiedzialnych za wykonywanie określonych zadań;

- zakres pokrywania się kompetencji;

- istnienie i stosowanie procedur eliminowania nakładania się kompetencji.

W ramach kryterium zarządzanie procesami:

- identyfikacja procesów realizowanych w urzędzie;

- określenie stanowisk odpowiedzialnych za realizowanie procesów;

- wykorzystanie wsparcia komputerowego w realizacji procesów;

- istnienie i stosowanie procedur monitorowania realizowanych procesów;

- istnienie i stosowanie procedur identyfikacji nowych procesów.

W ramach kryterium efektywność komunikacji wewnętrznej:

- ustanowione reguły komunikowania między burmistrzem i radą;

- ustanowione reguły komunikowania między burmistrzem i kierownikami;

- ustanowione reguły komunikowania w ramach urzędu;

- monitorowanie stosowanych reguł komunikowania oraz eliminowanie występujących nieprawidłowości.

Do obszarów, które pozostają do przeanalizowania w kolejnych etapach, należy zaliczyć (w myśl przyjętych rozwiązań):

1) zarządzanie strategiczne i finansowe:

- planowanie strategiczne; 
- perspektywiczna ocena sytuacji finansowej;

- wieloletnie planowanie inwestycyjne;

- roczne planowanie finansowe, monitorowanie i ocena wykonania planów;

2) zarządzanie kadrami:

- system rekrutacji personelu;

- system oceny i awansowania pracowników;

- system szkoleń i doskonalenia zawodowego;

3) usługi publiczne, w tym komunalne:

- standardy świadczenia usług publicznych;

- planowanie świadczenia usług publicznych;

- doskonalenie świadczenia usług publicznych;

4) stymulowanie rozwoju gospodarczego:

- posiadanie i realizacja programu rozwoju gospodarczego, opracowanego na podstawie strategii rozwoju gminy;

- stosowanie różnych kategorii narzędzi stymulowania rozwoju gospodarczego;

- informowanie lokalnych środowisk o realizowanym programie rozwoju gospodarczego;

- uwzględnienie w budżecie rocznym oraz wieloletnich planach finansowych środków finansowych na realizację przedsięwzięć wynikających z programu rozwoju gospodarczego;

- istnienie i stosowanie zasad prowadzenia monitoringu i oceny realizacji programu rozwoju gospodarczego;

- istnienie i stosowanie zasad aktualizacji programu rozwoju gospodarczego;

5) partycypacja społeczna i stymulowanie rozwoju społecznego:

- komunikacja i partycypacja społeczna;

- współpraca z organizacjami pozarządowymi;

- wspieranie inicjatyw społecznych;

6) zarządzanie projektami:

- realizacja zadań w formie projektów;

- istnienie systemu zarządzania projektami;

- stosowanie elementów systemu zarządzania projektami do realizacji zadań w formie projektów;

- szkolenie urzędników w zakresie zarządzania projektami;

7) etyka i zapobieganie zjawiskom korupcji:

- istnienie oraz stosowanie standardów zachowań etycznych radnych lub urzędników;

- istnienie oraz stosowanie szczegółowych procedur postępowania;

- szkolenie radnych i urzędników w zakresie stosowania standardów zachowań etycznych;

- istnienie i stosowanie mechanizmów oceny i doskonalenia obowiązujących standardów zachowań etycznych oraz szczegółowych procedur postępowania ${ }^{6}$.

\footnotetext{
${ }^{6}$ Analiza instytucjonalna gminy. Metoda planowania rozwoju instytucjonalnego, red. A. Szczepanik, M. Kukiełka, Uniwersytet Ekonomiczny w Krakowie Małopolska Szkoła Administracji Publicznej, Kraków 2010, s. 9.
} 
Kolejne etapy zostaną realizowane po wdrożeniu i ocenie efektów zmian dokonanych w wyniku przeprowadzonej już analizy, dla wymienionych obszarów i kryteriów zarządzania.

\section{ANALIZA OBSZARU ZARZADZANIA: ORGANIZACJA I FUNKCJONOWANIE URZĘDU - PREZENTACJA PRZEBIEGU ORAZ WYNIKÓW BADAŃ}

W obszarze tym uwaga koncentruje się na problematyce:

- struktury organizacyjnej i formalnej;

- procedur administracyjno-biurowych;

- komunikacji wewnętrznej w urzędzie.

Struktura organizacyjna i formalna (organizacja statyczna) jest rozumiana jako układ powiązanych wzajemnie komórek organizacyjnych (wydziałów) w urzędzie z uwzględnieniem takich aspektów, jak:

- podział uprawnień decyzyjnych pomiędzy radę i wójta (burmistrza lub prezydenta) oraz kierowników;

- podział zadań i odpowiedzialności za rezultaty realizacji zadań między komórki organizacyjne urzędu.

Procedury administracyjno-biurowe (organizacja dynamiczna) to reguły obowiązujące w urzędzie, które są niezbędne do realizacji zadań. W szczególności chodzi tu o:

- realizowane procesy (sekwencje działań i zakresy współpracy);

- wykorzystanie systemów informatycznych do realizacji procesów.

$\mathrm{Z}$ kolei komunikacja wewnętrzna w urzędzie to niezbędne przepływy informacyjnodecyzyjne, umożliwiające realizację procedur i sprawną koordynację działań. W urzędzie wyróżnia się dwie zasadnicze kategorie przepływu informacji:

- komunikację poziomą - przepływ informacji pomiędzy komórkami realizującymi zadania;

- komunikację pionową - przepływ informacji niezbędnej do wzajemnego zaspokojenia potrzeb informacyjnych kierowników (decydentów) i wykonawców (urzędników na niższych szczeblach).

W ramach obszaru zarządzania organizacja i funkcjonowanie urzędu sformułowano trzy kryteria zarządzania:

- podział uprawnień decyzyjnych i odpowiedzialności;

- zarządzanie procesami;

- efektywność komunikacji wewnętrznej.

Pierwsze kryterium zarządzania - podział uprawnień decyzyjnych i odpowiedzialności - obejmuje następujące zagadnienia:

- przejrzystość podziału kompetencji pomiędzy radą a wójtem (burmistrzem lub prezydentem);

- przejrzystość podziału kompetencji pomiędzy wójtem (burmistrzem lub prezydentem) i kierownikami;

- określenie stanowisk rozliczanych za rezultaty zrealizowanych zadań;

- określenie stanowisk odpowiedzialnych za wykonywanie określonych zadań;

- zakres pokrywania się kompetencji;

- istnienie i stosowanie procedur eliminowania nakładania się kompetencji. 
Drugie kryterium zarządzania - zarządzanie procesami - dotyczy następujących zagadnień:

- identyfikacja i formalizacja procesów realizowanych w urzędzie;

- określenie stanowisk odpowiedzialnych za realizowanie procesów;

- wykorzystanie wsparcia komputerowego w realizacji procesów;

- istnienie i stosowanie procedur monitorowania realizowanych procesów;

- istnienie i stosowanie procedur identyfikacji nowych procesów.

Trzecie kryterium zarządzania w obszarze organizacja i funkcjonowanie urzędu - efektywność komunikacji wewnętrznej - dotyczy takich zagadnień, jak:

- ustanowione reguły komunikowania między wójtem (burmistrzem lub prezydentem) i radą;

- ustanowione reguły komunikowania między wójtem (burmistrzem lub prezydentem) i kierownikami;

- ustanowione reguły komunikowania w ramach urzędu;

- monitorowanie stosowanych reguł komunikowania oraz eliminowanie występujących niesprawności.

\subsection{I etap. Budowa map procesów}

Prezentacja procesów to opis stanu faktycznego układu i przebiegu działań w określonej dziedzinie zarządzania. Opis ten stanowi odwzorowanie danego przedmiotu badania, czyli jego identyfikację. Dla potrzeb poglądowych w prezentacji procesów wykorzystuje się różne metody graficzne, do których przykładowo można zaliczyć: karty przebiegu czynności, wykresy Clarka, wykresy Bernatene-Grüna, wykresy Gantta, harmonogramy, schematy klasyfikacyjne, wykresy Sankeya, diagram Ishikawy, diagram relacji, mapy procesów. Graficzne prezentacje dają plastyczne wyobrażenie o konfiguracji procesów ${ }^{7}$.

Celem mapowania procesów realizowanych w poszczególnych wydziałach urzędu było wskazanie na podstawie regulaminu organizacyjnego dokładnego przebiegu poszczególnych czynności oraz usystematyzowanie właścicieli procesów. Tego rodzaju analiza była ułatwieniem przy wskazaniu osób odpowiedzialnych za poszczególne czynności. Procesowanie miało także na celu wskazanie przepływów komunikacyjnych i zależności między poszczególnymi komórkami organizacyjnymi urzędu.

Do wykonania map procesów wykorzystano udostępniony regulamin organizacyjny urzędu, który jako akt prawa wewnętrznego powinien odzwierciedlać zgodność struktury organizacyjnej z obowiązującymi procedurami oraz aktami prawnymi. Przy mapowaniu procesów zastosowano zasadę grupowania procesów, które ze swej natury są tożsame.

$\mathrm{Na}$ tym etapie dla wszystkich zidentyfikowanych procesów sporządzono mapy procesów. Przykładową mapę procesu przedstawiono na rysunku 2.

\footnotetext{
A. Stabryła, Ogólna koncepcja analizy i projektowania systemów zarządzania procesowego, „Zeszyty Naukowe Małopolskiej Wyższej Szkoły Ekonomicznej w Tarnowie" 21/2 (2012), s. 128.
} 
Rys. 2. Przyjmowanie, wysyłanie i rozdzielanie korespondencji na zewnątrz i wewnątrz urzędu

\begin{tabular}{|l|l|}
\hline \multicolumn{1}{|c|}{ Cel procesu } & \multicolumn{1}{|c|}{ Wlaściciel procesu (koordynujący) } \\
\hline $\begin{array}{l}\text { Zapewnienie sprawnej obsługi korespon- } \\
\text { dencji urzędu wewnątrz i na zewnątrz }\end{array}$ & $\begin{array}{l}\text { Naczelnik wydziału organizacyjnego z wy- } \\
\text { korzystaniem podległych pracowników }\end{array}$ \\
\hline
\end{tabular}

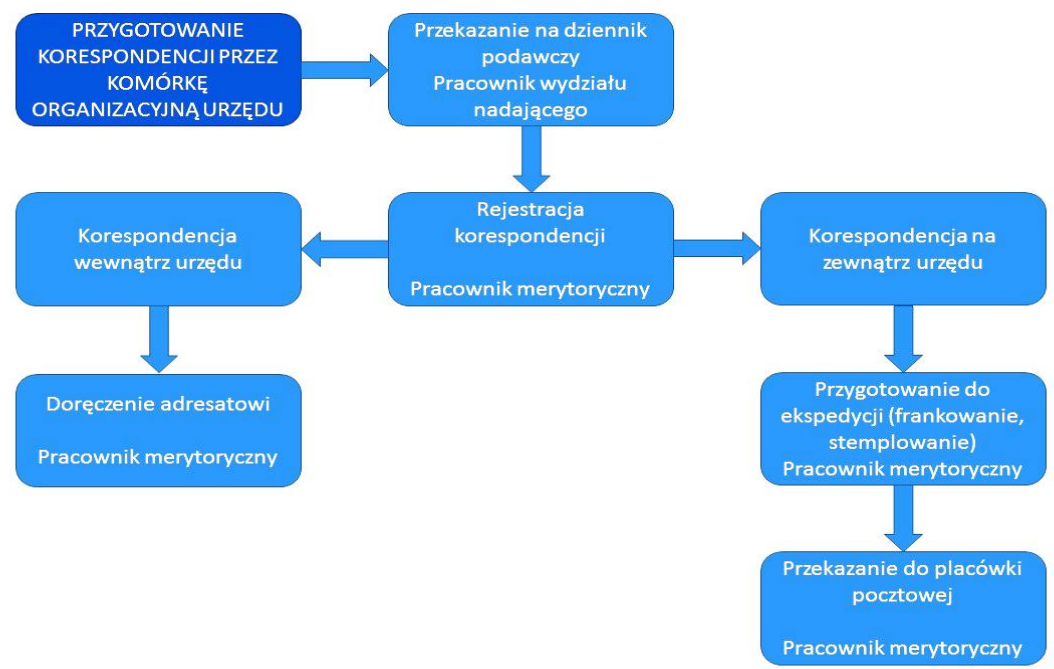

Źródło: opracowanie własne na podstawie przeprowadzonych badań.

Cele sporządzenia map procesów:

- $\quad$ wskazanie przebiegu procesów;

- wskazanie właścicieli procesów;

- $\quad$ wskazanie osób odpowiedzialnych za zadania (czynności);

- $\quad$ wskazanie zależności.

\subsection{II etap. Identyfikacja realizacji zadań}

W ramach prac w II etapie zostały zidentyfikowane wszystkie zadania realizowane w poszczególnych komórkach organizacyjnych, został im przypisany identyfikator oraz wskazano osobę odpowiedzialną za realizację (według przypisanego kodu) (tab. 1 i 2). 
Tabela 1. Identyfikacja zadania wraz ze wskazaniem osoby odpowiedzialnej za jego realizację

\begin{tabular}{|l|l|c|c|}
\hline Lp. Nazwa procesu & 2 \\
\hline 1 & $\begin{array}{l}\text { Obsługa organizacyjna wykonywania zadań przez burmistrza, } \\
\text { zastępcę burmistrza, sprawy kancelaryjno-techniczne }\end{array}$ & PWO-1 & Identyfikator* Kod \\
\hline 2 & $\begin{array}{l}\text { Prowadzenie spraw kadrowych urzędu ze szczególnym } \\
\text { uwzględnieniem prowadzenia akt osobowych pracowników } \\
\text { urzędu, pracowników zatrudnionych w ramach prac inter- } \\
\text { wencyjnych i robót publicznych }\end{array}$ & PWO-2 & 6 \\
\hline 2 a & $\begin{array}{l}\text { Czynności z zakresu prawa pracy wraz z wymaganymi reje- } \\
\text { strami, analizami i sprawozdawczością }\end{array}$ & PWO-2a & 6 \\
\hline 3 & $\begin{array}{l}\text { Prowadzenie rejestru umów-zleceń i umów o dzieło spisywa- } \\
\text { nych z osobami fizycznymi oraz spisywanie umów-zleceń i } \\
\text { umów o dzieło z osobami fizycznymi w zakresie prowadzo- } \\
\text { nych spraw, zapytania kierowane do Krajowego Rejestru } \\
\text { Karnego }\end{array}$ & PWO-3 & 6 \\
\hline 4 & $\begin{array}{l}\text { Przyjmowanie, wysyłanie i rozdzielanie korespondencji na } \\
\text { zewnątrz i wewnątrz urzędu }\end{array}$ & PWO-4 & 1,2 \\
\hline
\end{tabular}

Źródło: opracowanie własne na podstawie przeprowadzonych badań

Tabela 2. Przypisanie odpowiedzialności

\begin{tabular}{|c|c|}
\hline Imię i nazwisko pracownika & Kod \\
\hline p. $\mathbf{X}$ & 1 \\
\hline p. Y & 2 \\
\hline p. Z & 3 \\
\hline itd. & 4 \\
\hline
\end{tabular}

Źródło: opracowanie własne na podstawie przeprowadzonych badań.

\subsection{Etap III. Analiza wewnętrzna w poszczególnych komórkach organizacyjnych - przykład}

W kolejnym trzecim etapie zostały wskazane: liczba realizacji poszczególnych zadań (spraw), liczba pracowników obsługujących dane zadania oraz ilość korespondencji w danych komórkach organizacyjnych (tab. 3 i 4).

Tabela 3. Liczba spraw realizowanych w Wydziale Organizacyjnym

\begin{tabular}{|c|c|}
\hline Wskaźnik & Liczba \\
\hline Liczba spraw & 1139 \\
\hline Liczba pracowników & 6 \\
\hline Ilość korespondencji & 174 \\
\hline
\end{tabular}

Źródło: opracowanie własne na podstawie przeprowadzonych badań. 
Tabela 4. Liczba spraw realizowanych w Wydziale Finansów Gminnych

\begin{tabular}{|c|c|}
\hline Wskaźnik & Liczba \\
\hline Liczba spraw & Brak danych \\
\hline Liczba pracowników & 22 \\
\hline Ilość korespondencji & 5520 \\
\hline
\end{tabular}

Źródło: opracowanie własne na podstawie przeprowadzonych badań.

\subsection{Etap IV. Analiza porównawcza wydziałów}

W czwartym etapie dokonano zestawienia danych zgromadzonych w poprzednich etapach a dotyczących poszczególnych komórek organizacyjnych. Przykładową analizę przedstawiono na rysunku 3.

Rys. 3. Analiza porównawcza z zakresie: liczby spraw, liczby pracowników oraz ilości korespondencji w poszczególnych komórkach organizacyjnych urzędu

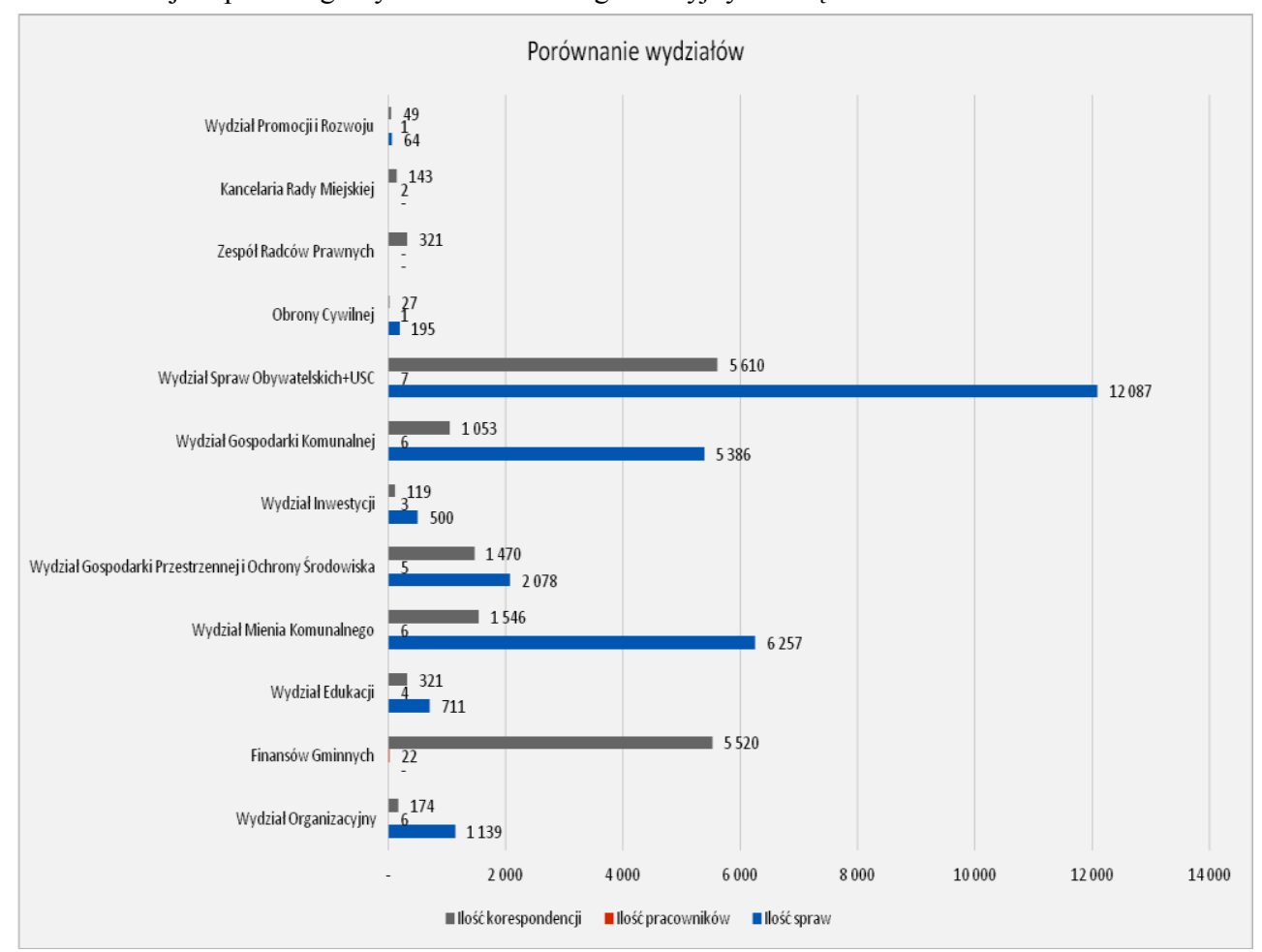

Źródło: opracowanie własne na podstawie przeprowadzonych badań. 


\subsection{Etap V. Formulowanie wniosków końcowych}

$\mathrm{Na}$ ostatnim etapie prac sformułowano wnioski i propozycje zmian dotyczące analizowanych obszarów i kryteriów zarządzania. Na przykład wskazano, że:

- w zakresie zadań Wydziału Organizacyjnego brakuje procesów dotyczących zarządzania informatyką;

- $\quad$ wskazanie - zaleca się dodanie do regulaminu organizacyjnego punktu $15 \mathrm{w} \S 21$ o treści: ,projektowanie i koordynowanie systemów komputerowych, administrowanie sieci komputerowej i teleinformatycznej, obsługa i aktualizacja oprogramowania komputerowego, prowadzenie ewidencji baz danych, archiwizowanie danych zapisanych na serwerach urzędu”. Co prawda $§ 21$ ust. 12 regulaminu wskazuje: „zaopatrywanie Urzędu w niezbędny sprzęt i wyposażenie w tym materiały biurowe i kancelaryjne". Przy analizowaniu przedmiotowego regulaminu można domniemywać, że w pojęciu „sprzęt i wyposażenie” ujęto także, w sposób dorozumiany, sprzęt informatyczny. Jednakże ze względu na charakter i wagę systemów informatycznych użytkowanych przez jednostkę należy w regulaminie organizacyjnym wprowadzić uszczegółowienie, o którym była już mowa. Regulamin ze swej natury powinien być pewnym schematem, który określa zasady działania poszczególnych agend urzędu. Biorąc pod uwagę natomiast rangę tego dokumentu jako wyznacznika zakresów czynności i odpowiedzialności poszczególnych komórek organizacyjnych, a tym bardziej delegację ustawową do wydania tego rodzaju dokumentu prawa wewnętrznego, powinien on spełniać funkcję normy bezwzględnie obowiązującej.

W zaleceniach dotyczących kolejnych kroków w realizacji zmian w urzędzie wskazano na potrzebę:

- $\quad$ określenia procesów strategicznych realizowanych w Urzędzie;

- $\quad$ zbudowania schematu zależności między wydziałami (konieczność uzgodnień);

- $\quad$ wskazanie zależności (wskazanie możliwości rozliczenia zadaniowego);

- opracowanie planu oszczędnościowego;

- $\quad$ opracowanie nowego regulaminu organizacyjnego;

- $\quad$ opracowanie nowych zakresów zadań dla wydziałów;

- $\quad$ opracowanie nowych zakresów czynności dla pracowników;

- $\quad$ przeprowadzenie ankiety ewaluacyjnej po dokonanych zmianach.

Identyfikacja, opis i zarządzanie procesami mają duży wpływ na doskonalenie zarządzania urzędem i obsługi klienta. Zdefiniowanie kluczowych procesów jest istotne, gdyż daje możliwość ustalenia części składowych procesu (czynności) oraz zapewnienia kontroli nad wykonywanymi działaniami, na przykład poprzez określenie celów i mierników. Identyfikacja procesów jest także wymagana do wdrożenia systemu zarządzania jakością według normy ISO 9001. Zarządzanie procesami jest również jednym z kryteriów używanych do oceny organizacji administracji publicznej w modelu CAF. Współcześnie przyjmuje się, że tradycyjne zarządzanie zadaniami urzędu poprzez wykonywanie zadań statutowych czy decyzji administracyjnych nie wystarcza do zapewnienia właściwej jakości oraz doskonalenia systemu obsługi klienta. Stąd też rosnące zainteresowanie wprowadzeniem rozwiązań w zakresie zarządzania procesami w administracji publicznej ${ }^{8}$.

\footnotetext{
${ }^{8}$ Katalog narzędzi rozwoju instytucjonalnego w samorzadzie lokalnym, red. M. Zawicki, UE w Krakowie Małopolska Szkoła Administracji Publicznej, Kraków 2011, s. 51
} 
Dzięki przeprowadzonym badaniom powstałe mapy procesów oraz opis procesów kluczowych urzędu umożliwiły zbudowanie mechanizmów pozwalających na kontrolę i doskonalenie podstawowych procesów wykonywanych przez poszczególne komórki organizacyjne urzędu.

\section{ZAKOŃCZENIE}

Zarządzanie to trudna dziedzina. W dobie dynamicznie zmieniającego się otoczenia każda organizacja chcąca sprawnie w nim funkcjonować powinna znać swoją w nim pozycję. Jeszcze trudniejsze wydaje się skuteczne zarządzanie w odniesieniu do jednostek samorządu terytorialnego. Ich zadania oraz misja, której głównym i nadrzędnym przesłaniem jest zaspokajanie potrzeb społeczności lokalności lokalnej, obligują tego typu organizacje do usprawniania swojego działania. Obecnie można zaobserwować rosnące zainteresowanie nowoczesnymi metodami planowania, analizy i zarządzania w sferze publicznej. Przeprowadzone badania pozwoliły na wskazanie władzom gminy niedoskonałości w organizacji pracy urzędu oraz realizowanych przez poszczególne komórki organizacyjne procesach. $\mathrm{W}$ trakcie badania przeanalizowano procesy $\mathrm{z}$ uwzględnieniem natężenia załatwianych spraw, ich różnorodności oraz liczby zaangażowanych pracowników. Przedstawiono procesy, których realizację należy zmienić, oraz wskazano, w jaki sposób tego dokonać. W efekcie badań opracowano szczegółowe mapy procesów dla każdego z działów. Po dokonaniu analiz zalecono konkretne zmiany organizacyjne i funkcjonalne.

Zaprezentowany przypadek małopolskiej gminy jest dowodem na zmiany zachodzące w świadomości rządzących. W tym wypadku władze doceniły wyniki badań, uwzględniły wskazane niedociągnięcia $\mathrm{w}$ funkcjonowaniu urzędu i sięgnęły po narzędzia umożliwiające zdiagnozowanie stanu faktycznego i sformułowanie zaleceń na przyszłość. Dzięki takim postawom można mieć nadzieję na coraz sprawniejsze zarządzanie urzędami, a w efekcie - wzrost zadowolenia i zaufania obywateli.

\section{LITERATURA}

[1] Analiza instytucjonalna gminy. Metoda planowania rozwoju instytucjonalnego, red. A. Szczepanik, M. Kukiełka, Uniwersytet Ekonomiczny w Krakowie Małopolska Szkoła Administracji Publicznej, Kraków 2010.

[2] Katalog narzędzi rozwoju instytucjonalnego w samorzadzie lokalnym, red. M. Zawicki, UE w Krakowie Małopolska Szkoła Administracji Publicznej, Kraków 2011.

[3] Materiały udostępnione przez urząd gminy (materiały źródłowe).

[4] Pawłowska A., Ocena poziomu rozwoju instytucjonalnego urzędu - doświadczenia urzędu miasta Częstochowy, „Zarządzanie Publiczne” 14/2 (2011).

[5] Rozwój instytucjonalny. Poradnik dla samorządów terytorialnych, red. S. Mazur, Małopolska Szkoła Administracji Publicznej Akademii Ekonomicznej w Krakowie, Kraków 2004.

[6] Stabryła A., Ogólna koncepcja analizy i projektowania systemów zarządzania procesowego, „Zeszyty Naukowe Małopolskiej Wyższej Szkoły Ekonomicznej w Tarnowie” 21/2 (2012).

[7] Wojciechowski E., Zarządzanie w samorządzie terytorialnym, Difin, Warszawa 2003.

\section{THE CHALLENGES OF MODERN MANAGEMENT IN LOCAL GOV- ERNMENT UNITS IN THE FACE OF CHANGE - CASE STUDY}

The functioning of the local administration may have a significant impact on the development of the local community. Past practice shows, however, unfortunately, that in the 
case management processes in local authorities, often we have to deal only with the administration than management system. Management,in contrast to the administration, it should be a process, which includes the activity and creativity.

The article is devoted to the methods of reorganization, streamlining work serving local government units. The focus is on one of the selected methods - the method of institutional development. The method institutional development offices, includes an analysis of the level of institutional development, design changes (improvements) institutional, their implementation and monitoring and evaluation of the results. With the observation of specified areas of management, according to specific criteria, you can identify strengths and weaknesses in them occurring, and on this basis, the researcher is able to identify gaps and ways to make improvements.

Institutional analysis applies to the nine areas of the office. The article describes an analysis of one of the areas namely the organization and functioning of the Office. The analysis was performed based on one of the Malopolska offices of the municipality in the 2015. The analysis of the organization and functioning of the office is based on the model of institutional analysis. The article presents the results of analysis of the selected area and office management criteria.

Keywords: management, management in local government units, new public management, organization and management of the city hall

\section{DOI: 10.7862/rz.2016.mmr.22}

Tekst złożono w redakcji: kwiecień 2016

Przyjęto do druku: wrzesień 2016 